\title{
Metabolism of oestrone and oestradiol-17 $\beta$ to conjugated steroids by the accessory sex glands of the male pig
}

\author{
J I Raeside, H L Christie and R L Renaud
}

Department of Biomedical Sciences, University of Guelph, Guelph, Ontario, Canada N1G 2W1

(Requests for offprints should be addressed to J I Raeside)

\begin{abstract}
Oestrogens are secreted in large amounts by boar testes and are known to have a synergistic effect with testosterone on the production of large volumes of seminal plasma. Thus, oestrogens play a role in regulating the large accessory sex glands in the boar. Since testosterone metabolites (e.g. $5 \alpha$-dihydrotestosterone) account for much of its action in target tissues we have looked at the metabolism of oestrogens in the accessory sex glands of the male pig. Tissues from seminal vesicles and bulbourethral glands of 6-week-old castrate and intact males, and 12-week-old castrate animals, were incubated with ${ }^{3} \mathrm{H}$-labelled oestrone and oestradiol-17 $\beta$. Aliquots of spent culture medium and of methanolic tissue extracts were taken to measure radioactivity, prior to separation of unconjugated and
\end{abstract}

conjugated steroids on Waters $\mathrm{C}_{18}$ Sep-Pak cartridges. About one-third of the radioactivity appeared as conjugates in the media from both glands with each oestrogen. Subsequently, sulphoconjugated steroids and glucuronidates were recovered in series from $\mathrm{C}_{18}$ cartridges after solvolysis and enzyme hydrolysis respectively. Furthermore, about one-third of the conjugated fraction in each case remained unhydrolysed after these treatments. In conclusion, it is clear that a study of the actions of oestrogens on these glands must consider the dynamics of metabolism of the oestrogens presented to them by the testes and would include conjugation of steroids by the glands themselves.

Journal of Endocrinology (1999) 163, 49-53

\section{Introduction}

Compared with males of most other species the testes of the boar secrete large amounts of oestrogens (Velle 1958, Raeside 1965, Claus \& Hoffman 1980). Most of this secretion is in the form of oestrogen sulphates (Raeside 1966, Raeside \& Renaud 1983, Setchell et al. 1983, Orava et al. 1985) and its significance is largely unknown. In spite of a heightened interest in oestrogens in the male in recent years (Sharpe \& Skakkebaek 1993, Smith et al. 1994, Hess et al. 1997a), a specific physiological role had not been demonstrated until the study by Hess et al. (1997b) on the action of oestradiol on the efferent tubules of the testes and its significance for fertility in the mouse.

The extent and development of the accessory glands, and the volume of the ejaculate in the boar greatly exceed those of other farm animals (McKenzie et al. 1938). Although details are lacking on the nature of the hormonal control of these glands, it is clear from castration that their dependence on the testes is paramount. Some early studies have addressed the action of oestrogens on the accessory genital organs in a variety of animals (for review see Burrows 1949); these reports were almost exclusively on morphological findings. It was concluded that a small supply of oestrogen appears to be favourable if not essential for the well-being of the male accessory reproductive organs. In more physiological terms, it was demonstrated later (Joshi \& Raeside 1973) that oestrogens act synergistically with testosterone on the accessory sex glands and on the sexual behaviour of the boar. Because the action of testosterone depends in such large measure on its further metabolism in target cells (Mainwaring 1977), we wished to determine to what extent the response to an oestrogen might similarly relate to its metabolism in the male reproductive system. The present report describes our initial study in which the aim was to see if oestrogens are metabolised by the seminal vesicles and bulbourethral glands in the domestic pig. In view of the high plasma concentrations of oestrogens during the first month after birth (Schwartzenberger et al. 1993), comparable to those of the adult male, we have used readily available, younger animals in our initial work.

\section{Materials and Methods}

\section{Materials}

Radiolabelled $\left[2,4,6,7-{ }^{3} \mathrm{H}\right]$ oestrone $(101 \mathrm{Ci} / \mathrm{mmol})$ and $\left[2,4,6,7-{ }^{3} \mathrm{H}\right]$ oestradiol $(83 \mathrm{Ci} / \mathrm{mmol})$ were obtained from Amersham Canada Ltd (Oakville, Ontario, Canada). Non-radioactive steroids were purchased from Steraloids Inc. (Wilton, NH, USA). 
Solvents were glass-distilled, reagent-grade from Caledon Laboratories Ltd (Georgetown, Ontario, Canada). Sep-Pak $\mathrm{C}_{18}$ cartridges were purchased from Waters Scientific (Mississauga, Ontario, Canada). Both $\beta$-glucuronidase (type B-1, from beef liver) and glucuronidase-sulphatase (crude solution type HP-2, from Helix pomatia) were supplied by Sigma (St Louis, MO, USA). All other chemicals were of analytical grade and were obtained from Sigma or Fisher Scientific (Toronto, Canada).

\section{Preparation and incubation of tissues}

Seminal vesicles (SV) and bulbourethral (BU) glands were removed at euthanasia from 6 -week-old piglets $(n=6$ and $n=8$, castrates; $n=12$, intact males) and from three 12 -week-old castrate males. The glands were dissected free of extraneous tissues, weighed, minced finely by hand or with a McIlwain Tissue Chopper, and pooled before dividing into equal portions. Individual weights of SV and BU glands were similar within experiments and were about $0 \cdot 2-0.3 \mathrm{~g}$ for both younger castrate groups, and 0.7 and $0.9 \mathrm{~g}$ for 6 -week-old intact and 12 -week-old castrate males respectively. The amount of tissue dispensed was approximately the same for both types of glands in each experiment, and ranged from 0.145 to $0.725 \mathrm{~g}$ (wet weight) per flask. Tissues were incubated for $2 \mathrm{~h}$ in $5 \mathrm{ml}$ culture medium (TC-199) in 25-ml Ehrlenmeyer flasks at $34{ }^{\circ} \mathrm{C}$ under $5 \% \mathrm{CO}_{2}: 95 \%$ air in a shaking waterbath, with ${ }^{3} \mathrm{H}$-labelled oestrogens (about $2 \times 10^{6}$ c.p.m., in duplicate or triplicate). After incubation, the samples were stored at $-20{ }^{\circ} \mathrm{C}$ until processed as follows. The thawed contents of each flask were separated into a medium and a tissue pellet fraction and an aliquot of the medium (1/100th) was taken to measure radioactivity. The tissue pellet was washed twice with $1 \mathrm{ml}$ distilled water which was combined with the spent medium, and then the pellet was extracted $(2 \times 5 \mathrm{ml}$ methanol $)$. The methanol extracts were combined and an aliquot $(1 / 100$ th) taken for liquid scintillation counting.

\section{Analytical procedures}

Steroids in the media were recovered by solid-phase extraction (Waters $\mathrm{C}_{18}$ Sep-Pak cartridges) as described previously (Raeside et al. 1997b). Unconjugated and conjugated steroids were eluted from the primed cartridges with, successively, $5 \mathrm{ml}$ diethyl ether and $5 \mathrm{ml}$ methanol. The ether and methanol eluates were evaporated separately under nitrogen at $<45{ }^{\circ} \mathrm{C}$. The conjugated material underwent two hydrolytic processes in series; in each case, the recovery of steroids from Sep-Pak cartridges was as described above. These steps were briefly as follows: the dried methanol (conjugate) fraction from the first cartridge was acid solvolysed overnight at $45^{\circ} \mathrm{C}$ with trifluoroacetic acid/ethyl acetate $(1 / 100, \mathrm{v} / \mathrm{v})$ to obtain a 'sulphate' fraction, as free steroids, and the conjugated material (methanol eluate) from the second cartridge was submitted to enzyme hydrolysis using one of two sources of enzyme. The dried methanol fraction was reconstituted in $0.5 \mathrm{ml}$ $0.5 \mathrm{M}$ sodium acetate buffer ( $\mathrm{pH} 5 \cdot 0$ ), and 1250 units $\beta$-glucuronidase (type B-1, from beef liver) or 3400 units glucuronidase (type HP-2, snail extract) were added in $25 \mu \mathrm{l}$ of the buffer for incubation at $37^{\circ} \mathrm{C}$ overnight. Free steroids obtained at this stage (third cartridge) were designated as the 'glucuronidate' fraction, and the nonhydrolysed steroids eluted with methanol were considered to be conjugated in an unknown form(s).

Distribution of radioactive material for each incubation was determined by liquid scintillation counting in $5 \mathrm{ml}$ cocktail (Ecolite, ICN Pharmaceuticals Inc., Radiochemical Products, Irvine, CA, USA), by taking an aliquot of the medium or tissue extract before solid phase extraction on Sep-Pak $\mathrm{C}_{18}$ cartridges. Similarly, the dried eluates of subsequent separations on $\mathrm{C}_{18}$ cartridges were dissolved in methanol and aliquots removed for counting radioactivity. This was done at each stage in a series and thus served also as a means of ensuring that sufficient radioactive material was taken for a reliable estimation of its distribution at the next step.

\section{Statistical analysis}

Data were expressed as means \pm S.D. Statistical analysis was carried out using Student's $t$-test with statistical significance defined as $P<0 \cdot 05$.

\section{Results}

\section{Distribution of radioactivity after incubation}

The initial distribution of radioactivity between the incubation medium and tissue extracts revealed that most of it $(>70 \%)$ was present in the medium. Combined data for recovery from the media for both glands from castrate and intact animals showed significantly higher values $(P<0 \cdot 05)$ with oestradiol than with oestrone (means \pm S.D., $92 \cdot 5 \pm 2 \cdot 3$ and $77 \cdot 8 \pm 4 \cdot 8 \%$ respectively). In this report, data on the nature of the radioactive material are given for the media only.

\section{Unconjugated versus conjugated fractions}

The distribution of radioactivity for both $\mathrm{SV}$ and $\mathrm{BU}$ glands was similar in each experiment with both oestrone (E1) and oestradiol (E2). The mean values for the conjugated fractions were about $30 \%$ (SV: $\mathrm{E} 1=29 \cdot 7 \pm 3 \cdot 3$, $\mathrm{E} 2=28 \cdot 7 \pm 6 \cdot 7 ; \quad$ BU: $\quad \mathrm{E} 1=32 \cdot 9 \pm 7 \cdot 6, \quad \mathrm{E} 2=32 \cdot 7 \pm 7 \cdot 2)$. Overall losses at this separation step were about $10-15 \%$ with the major component in the 'flow-through' fraction, before elution of the 'free' steroids from the cartridge; they 
Table 1 Distribution of radioactivity in the media after a 2-h incubation, in triplicate, of pooled tissues from three, 12-week-old, castrate male pigs. Values are given as percentages of total c.p.m. (means \pm S.D.). Losses were about $10-15 \%$ and occurred mainly at the solid-phase extraction step

\begin{tabular}{|c|c|c|c|c|}
\hline & \multicolumn{2}{|c|}{ Seminal vesicles } & \multicolumn{2}{|c|}{ Bulbourethral glands } \\
\hline & Oestrone & Oestradiol & Oestrone & Oestradiol \\
\hline \multicolumn{5}{|l|}{ Fraction } \\
\hline Free steroids & $57 \cdot 3 \pm 3 \cdot 8$ & $58 \cdot 7 \pm 2 \cdot 5$ & $58 \cdot 0 \pm 0 \cdot 8$ & $58 \cdot 7 \pm 1 \cdot 7$ \\
\hline Sulphates & $8 \cdot 5 \pm 0.9$ & $8 \cdot 3 \pm 1 \cdot 7$ & $11 \cdot 7 \pm 1 \cdot 5$ & $11 \cdot 2 \pm 3 \cdot 2$ \\
\hline Glucuronidates & $5 \cdot 9 \pm 0 \cdot 5$ & $4 \cdot 3 \pm 1 \cdot 4$ & $4 \cdot 9 \pm 2 \cdot 3$ & $4 \cdot 5 \pm 0.9$ \\
\hline Non-hydrolysed & $13 \cdot 8 \pm 0 \cdot 9$ & $12 \cdot 6 \pm 1 \cdot 3$ & $11 \cdot 5 \pm 1 \cdot 4$ & $12 \cdot 6 \pm 0 \cdot 7$ \\
\hline
\end{tabular}

were not investigated further. Supporting evidence for conjugation was obtained from incubations with competing amounts of non-radioactive oestrone (10 and $50 \mu \mathrm{g})$. The amount of radioactivity eluted with methanol was reduced by 30 and $47 \%$ for the SV, and by 46 and $62 \%$ for the $\mathrm{BU}$ glands respectively. In addition, no conjugation was seen when boiled tissues were used $(<2 \%$ in the methanol fraction).

\section{Sulphates versus non-solvolysed steroids}

The combined results from all experiments showed that the relative amounts of radioactivity appearing in the solvolysed ('sulphate') fraction of the conjugated material were similar for both substrates for the seminal vesicles $(\mathrm{E} 1=31 \cdot 7 \pm 2 \cdot 7, \mathrm{E} 2=32 \cdot 0 \pm 4 \cdot 3 \%)$. Similarly, the values for the BU glands were essentially the same for the two substrates (E1=49.4 $\pm 11 \cdot 0, \quad E 2=51 \cdot 3 \pm 13 \cdot 2 \%)$. Relatively more radioactivity, therefore, was present as sulphoconjugated products after incubation of the substrates with the $\mathrm{BU}$ glands $(P<0 \cdot 05)$.

\section{Glucuronidates and other conjugates}

When the non-solvolysed material from the solvolysis step was submitted to an enzyme hydrolysis with $\beta$-glucuronidase the radioactivity was further divided into a free ('glucuronidate') fraction and an amount remaining in a conjugated form(s). Only $30-35 \%$ of the radioactivity appeared as glucuronidates (SV: $\mathrm{EI}=30 \cdot 2 \pm 3 \cdot 7, \mathrm{E} 2=$ $30 \cdot 3 \pm 4 \cdot 1$; BU: $\mathrm{E} 1=34 \cdot 6 \pm 5 \cdot 6$, E2 $=27 \cdot 3 \pm 11 \cdot 9 \%$ ), with most remaining as 'non-hydrolysed' metabolites (>65\%). In a single experiment with each gland and substrate, an attempt to recover more glucuronidates with a second enzyme hydrolysis yielded little additional material (10$14 \%)$. The variability in the combined data was largely due to variation between experiments. No further statistical analysis was carried out because of low numbers of replicates in each case. Data for the overall distribution in one experiment are given (Table 1) and with incubations carried out in triplicate the consistency of the findings is clearly shown.

\section{Discussion}

Although the biological action of testosterone in many target cells depends on its metabolism, principally to $5 \alpha$-dihydrotestosterone (Mainwaring 1977), there is little or no evidence that the actions of oestrogens involve a local metabolism beyond that of $17 \beta$-hydroxysteroid dehydrogenases (Labrie et al. 1997). Booth (1983) reported that minces of prostate and seminal vesicles of mature intact boars more readily converted oestrone to oestradiol-17 $\beta$ than vice versa. No such interconversion of the oestrogens was seen in preliminary HPLC studies of the metabolites from incubations of tissues from the young animals in our experiments (J I Raeside, H L Christie \& R L Renaud, unpublished data). To test whether oestrogenic responses in target tissues are influenced by other enzymes in an extrahepatic site of metabolism of oestrone and oestradiol, we have undertaken studies on the accessory sex glands of the domestic male pig. As noted above, boars are remarkable for their high production of oestrogens by the testes and the secretion of large volumes of fluids from the accessory sex glands. Furthermore, our earlier work had suggested that oestrogens acted synergistically with testosterone on these glands (Joshi \& Raeside 1973). In the present study we have used younger animals which are known to respond to the high levels of testicular steroids seen in the postnatal period in the pig (Raeside et al. 1997a, Schwartzenberger et al. 1993).

Most of the radioactivity (70-95\%) after incubation of tissues with the ${ }^{3} \mathrm{H}$-labelled oestrogens was found to be present in the media. Therefore, an examination for evidence of metabolism has been restricted initially to that material. The first finding of interest was a consistent distribution of radioactivity in which a significant component (about 30\%) was recovered in the conjugated fraction. No radioactivity was seen in the conjugate fractions when boiled tissues were subsequently incubated 
with ${ }^{3} \mathrm{H}$-oestrogens. Further evidence that oestrogen conjugation can occur in the SV and BU glands was provided indirectly from the reduction seen when nonradioactive oestrone was added for competitive inhibition in some incubations. Although we have not fully identified the nature of the conjugation, this is the first evidence, as far as we are aware, of oestrogen conjugation by male accessory sex glands of a mammalian species. The physiological significance of oestrogen conjugation locally by the target tissues of the male reproductive glands in young piglets remains unknown.

Sulphotransferase activity appears to be present in these glands. Recent reviews on steroid sulphotransferases (Hobkirk 1993, Strott 1996) record no reports of such enzyme activity for oestrogens in the male reproductive tract. It may be noted that pig Leydig cells contain a sulphotransferase enzyme, distinct from the neutral steroid sulphotransferases (Hobkirk et al. 1989). Steroid sulphotransferase activity has also been demonstrated with dehydroepiandrosterone in the reproductive tract of the hamster (Bouthillier et al. 1984), but no assays were made with oestrogens as substrate. However, somewhat paradoxically, we have observed some hydrolysis of oestrone sulphate by both glands (J I Raeside, H L Christie, R L Renaud, unpublished data), as noted previously by Booth (1983). Because testicular secretion of oestrone and its circulation in peripheral blood are principally in the form of oestrone sulphate (Booth 1980, Claus \& Hoffman 1980, Setchell et al. 1983) such hydrolysis in vitro may imply physiological significance.

Hydrolysis of non-solvolysed steroids by $\beta$ glucuronidase indirectly revealed the presence of glucuronosyltransferase for oestrogens in both SV and BU glands of the pig. It seems reasonable to suggest that glucuronosyltransferase may play a role in oestrogen action in the SV and BU glands of the pig, similar to its regulation of androgen action in human prostatic cancer cells (Guillemette et al. 1996). While the liver is recognised as the major site of glucuronidation, it is clear that extrahepatic tissues are also involved (Dutton 1978). Much work has been done by Belanger and his group on glucuronidation of $5 \alpha$-reduced $\mathrm{C}_{19}$ steroids by normal and cancerous tissue from the human prostate (Belanger et al. 1991, Guillemette et al. 1996, Beaulieu et al. 1997, Belanger et al. 1997, 1998). They also characterised a novel uridine diphosphate glucuronosyltransferase isolated from the prostate of the cynomolgous monkey which was active on $\mathrm{C}_{18}$, as well as on $\mathrm{C}_{19}$ and $\mathrm{C}_{21}$, steroids (Belanger et al. 1997). Apart from catecholoestrogens, however, they saw no activity towards the phenolic oestrogens, which is in contrast to our findings with oestrone and oestradiol.

As a final point, we were surprised to find the extent to which the hydrolyses steps were unable to liberate all of the oestrogens in the conjugate fractions. Further efforts with solvolysis, sulphatase and $\beta$-glucuronidase failed to yield additional free radioactive material $(<10 \%$, data not shown). Thus there appeared to be another form(s) of oestrogen conjugation taking place in the porcine SV and $\mathrm{BU}$ glands. Both the nature of the conjugation and the steroid composition of the unhydrolysed fractions remain as subjects for future investigation. Even in their present form, however, the data point to the need to consider steroid conjugation in situ as a significant component of the metabolic fate of the hormone when examining the biological actions of oestrogens in target tissues of the male reproductive system.

\section{Acknowledgements}

We thank Dr R M Friendship, Department of Population Medicine, University of Guelph, for help in the collection of pig glands. This research was supported by the Natural Sciences and Engineering Research Council of Canada and the Ontario Ministry of Agriculture, Food and Rural Affairs.

\section{References}

Beaulieu M, Levesque E, Tchernof A, Beatty BG, Belanger A \& Hum D 1997 Chromosomal localization, structure, and regulation of the UGT2B17 gene, encoding a C19 steroid metabolizing enzyme. DNA Cell Biology 16 1143-1154.

Belanger A, Brochu M, Lacoste D, Noel C, Labrie F, Dupont A, Cusan L, Caron S \& Couture J 1991 Steroid glucuronides: human circulatory levels and formation by LNCaP cells. Journal of Steroid Biochemistry and Molecular Biology 40 593-598.

Belanger G, Beaulieu M, Levesque E, Hum DW \& Belanger A 1997 Expression and characterization of a novel UDP-glucuronosyltransferase, UGT2B9, from cynomolgus monkey. DNA Cell Biology 16 1195-1205.

Belanger A, Hum DW, Beaulieu M, Levesque E, Guillemette C, Tchernof A, Belanger G, Turgeon D \& Dubois S 1998 Characterization and regulation of UDP-glucuronosyltransferases in steroid target tissues. Journal of Steroid Biochemistry and Molecular Biology 65 301-310.

Booth WD 1980 A study of some major testicular steroids in the pig in relation to their effect on the development of male characteristics in the prepuberally castrated boar. Journal of Reproduction and Fertility 59 155-162.

Booth WD 1983 In vivo metabolism of unconjugated androgens, oestrogens and the sulphate conjugates of androgens and oestrone by accessory sex organs of the mature domestic boar. Journal of Endocrinology 96 457-464.

Bouthillier M, Bleau G, Chapdelaine A \& Roberts KD 1984 Distribution of steroid sulfotransferase in the male hamster reproductive tract. Biology of Reproduction 31 936-941.

Burrows H 1949 Biological Actions of Sex Hormones, edn 2, pp 351-359. Cambridge: Cambridge University Press.

Claus R \& Hoffman B 1980 Oestrogens compared with other steroids of testicular origin in blood plasma of boars. Acta Endocrinologica 94 404-411.

Dutton GJ 1978 Developmental aspects of drug conjugation, with special reference to glucuronidation. Annual Review of Pharmacology and Toxicology 18 17-35.

Guillemette C, Hum DW \& Belanger A 1996 Evidence for a role of glucuronosyltransferase in the regulation of androgen action in the human prostatic cancer cell line LNCaP. Journal of Steroid Biochemistry and Molecular Biology 57 225-231. 
Hess RA, Gist DH, Bunick D, Lubahn DB, Farrell A, Bahr J, Cooke PS \& Green GL 1997a Estrogen receptor $(\alpha$ and $\beta$ ) expression in the excurrent ducts of the adult rat reproductive tract. Journal of Andrology 18 602-611.

Hess RA, Bunick D, Lee K-H, Bahr J, Taylor JA, Korach KS \& Lubahn DB 1997b A role for oestrogens in the male reproductive system. Nature 390 509-512.

Hobkirk R 1993 Steroid sulfation: current concepts. Trends in Endocrinology and Metabolism 4 69-74.

Hobkirk R, Renaud R \& Raeside JI 1989 Partial characterization of steroid sulfohydrolase and steroid sulfotransferase activities in purified porcine Leydig cells. Journal of Steroid Biochemistry and Molecular Biology 32 387-392.

Joshi HS \& Raeside JI 1973 Synergistic effects of testosterone and oestrogens on accessory sex glands and sexual behaviour of the boar. Journal of Reproduction and Fertility 33 411-423.

Labrie F, Luu-The V, Lin SX, Labrie C, Simard J, Breton R \& Belanger A 1997 The key role of $17 \beta$-hydroxysteroid dehydrogenases in sex steroid biology. Steroids 62 148-158.

McKenzie FF, Miller JC \& Bauguess LC 1938 The reproductive organs and semen of the boar. Research Bulletin of the Missouri Agricultural Experimental Station, no. 279.

Mainwaring WIP 1977 The mechanism of action of androgens. Monographs on Endocrinology 10. New York: Springer-Verlag.

Orava M, Haour F, Leinonen P, Ruokonen A \& Vihko R 1985 Relationships between unconjugated and sulphated steroids in porcine primary Leydig cell culture. Journal of Steroid Biochemistry 22 507-512.

Raeside JI 1965 Urinary excretion of dehydroepiandrosterone and oestrogens by the boar. Acta Endocrinologica 50 611-620.

Raeside JI 1966 Secretion of steroid sulfates by the testes of the boar. Proceedings of the Canadian Federation of Biological Societies, vol 9, p 52. London, Ontario: Hunter Printing Ltd.
Raeside JI \& Renaud RL 1983 Estrogen and androgen production by purified Leydig cells of mature boars. Biology of Reproduction 28 727-733.

Raeside JI, Friendship RM \& Vrablic OE 1997a Effects of castration on early postnatal development of male accessory sex glands in the domestic pig. European Journal of Endocrinology 137 287-292.

Raeside JI, Renaud RL \& Christie HL 19976 Postnatal decline in gonadal secretion of dehydroepiandrosterone and $3 \beta$-hydroxyandrosta-5,7dien-17-one in the newborn foal. Journal of Endocrinology 155 277-282.

Schwartzenberger F, Toole GS, Christie HL \& Raeside JI 1993 Plasma levels of several androgens and estrogens from birth to puberty in male domestic pigs. European Journal of Endocrinology 128 173-177.

Setchell BP, Laurie MS, Flint APF \& Heap B 1983 Transport of free and conjugated steroids from the boar testis in lymph, venous blood and rete testis fluid. Journal of Endocrinology 96 127-136.

Sharpe RM \& Skakkebaek NE 1993 Are estrogens involved in falling sperm counts and disorders of the male reproductive tract? Lancet 341 1392-1395.

Smith EP, Boyd J, Frank GR, Takahashi H, Cohen RM, Specker B, Williams TC, Lubahn DB \& Korach KS 1994 Estrogen resistance caused by a mutation in the estrogen-receptor gene in a man. New England Journal of Medicine 331 1056-1061.

Strott CA 1996 Steroid sulfotransferases. Endocrine Reviews 17 670-697.

Velle W 1958 Isolation of oestrone and oestradiol-17 $\beta$ from the urine of adult boars. Acta Endocrinologica 28 255-261.

Received 18 December 1998

Revised manuscript received 26 April 1999

Accepted 27 May 1999 